7. Shlipak, M. G. et al. Should the Electrocardiogram Be Used to Guide Therapy for Patients With Left Bundle-Branch Block and Suspected Myocardial Infarction? JAMA281, 714719 (1999).

8. Nestelberger, T. et al. Diagnosis of acute myocardial infarction in the presence of left bundle branch block. Heart105, 1559-1567 (2019)

9. Poprawski, K., Piszczek, I., Smukowski, T. \& Paradowski, S. Comparison of the diagnostic value of echocardiographic, ecg and enzymatic investigations in acute myocardial infarction. Pol Arch Med Wewn85, 167-173 (1991).

\title{
ĐẶC ĐIỂM LÂM SÀNG VÀ CÂN LÂM SÀNG CỦA VIÊM ÂM ĐẠO KHÔNG ĐẶC HIỆU TẠI BỆnH VIỆN DA LIỄU TRUNG ƯƠ'NG
}

\section{TÓM TẮT}

Mục tiêu: Mô tả đặc điểm lâm sàng và cân lâm sàng của viêm âm đạo không đặc hiệu tại Bệnh viện Da liễu Trung ương từ tháng 8/2020 - 8/2021. Đối tượng và phương pháp: Mô tả cắt ngang trên 39 bệnh nhân được chẩn đoán xác định viêm âm đạo không đăc hiệu bằng tiêu chuẩn Amsel đến khám trong thời gian nghiên cứu. Kết quả: Bệnh thường gặp ở nhóm tuối từ 18-30 tuối $(66,6 \%)$. Tiền sử sản phụ khoa liên quan nạo hút thai $33,3 \%$, sảy thai $10,3 \%$. Đa số bênh nhân có triêu chứng cơ năng $(61,5 \%)$, trong đó, thường gặp mùi khí hư $(79,5 \%)$, ngứa rát âm hộ $(48,7 \%)$, giao hợp đau $(33,3 \%)$. Khám âm hộ âm đạo phát hiện $61,5 \%$ trường hợp viêm đỏ, đa số dịch nhiêu $69,2 \%$. Test sniff và tế bào clue dương tính ở $100 \%$ trường hợp, $66,7 \%$ có số lượng trực khuẩn gram âm từ 2+ trở lên, $94,9 \%$ số lượng lactobacilli từ 1+ trở xuống, độ lactobacilli IIb chiếm $51,3 \%$, độ III 23,1\%. Phân loại hệ vi sinh vật theo Nugent có $59 \%$ từ $4-6$ điểm và $41 \%$ từ $7-10$ điểm. Kết luận: Viêm âm đạo không đặc hiệu có xu hướng gặp ở phụ nữ trẻ, liên quan đến tiền sử thai sản và có biểu hiện rối loạn hệ vi sinh vật tại âm đạo.

Tứ khóa: Viêm âm đạo khổng đặc hiệu, lactobacilli

\section{SUMMARY}

\section{CLINICAL AND SUBCLINICAL CHARACTERISTICS} OF PATIENT WITH BACTERIAL VAGINOSIS AT NATIONAL HOSPITAL OF DERMATOLOGY AND VENEREOLOGY

Objectives: To investigate clinical and subclinical characteristics of bacterial vaginosis (BV) at National Hospital of Dermatology and Venereology from August 2020 to August 2021. Population and methods: Cross-sectional description of thirdty-nine patients with bacterial vaginosis who were diagnosis by Amsel'criteria. Results: BV was common in the age group of $18-30$ years old (66.6\%). History of obstetrics and gynecology related to abortion 33.3\%,

*Đại học Y Hà Nội

**Bệnh viện Da liễu Trung Uơng

Chịu trách nhiệm chính: Trần Cẩm Vân

Email: trancamvan.dl@gmail.com

Ngày nhận bài: 24.8.2021

Ngày phản biên khoa hoc: 18.10.2021

Ngày duyệt bài: 29.10.2021

\section{Trần Thị Lệ Giang*, Trần Cẩm Vân**}

miscarriage $10.3 \%$. The majority of patients had patient's symptoms $(61.5 \%)$, in which, vaginal odor $(79.5 \%)$, itching $(48.7 \%)$, painful intercourse $(33.3 \%)$ were common. Vaginal examination detected $61.5 \%$ of cases of red inflammation, most of the fluid was $69.2 \%$. Sniff test and clue cells were positive in $100 \%$ of cases, $66.7 \%$ had gram-negative bacilli of $2+$ or more, $94.9 \%$ had $1+$ or less of lactobacilli, lactobacilli IIb accounted for $51.3 \%$, grade III $23.1 \%$. Classification of microorganisms according to Nugent had $59 \%$ from $4-6$ points and $41 \%$ from $7-10$ points. Conclusion: Bacterial vaginosis tends to be seen in younger women, is associated with a history of pregnancy, and presents with disturbances in the vaginal flora.

Key words: Bacterial vaginosis, lactobacilli

\section{I. ĐẶT VẤN ĐỀ}

Viêm âm đạo không đặc hiệu (Bacterial vaginosis-BV) là một dạng thường gặp của viêm âm đạo, đặc trưng bởi sự mất cân bằng vi hệ tự nhiên tại âm đạo. Nguyên nhân là do suy giảm số lượng vi khuẩn lactobacilli và phát triển quá mức của nhiều nhóm vi khuẩn khác nhau trong đó đăc biệt Gardnerella vaginalis, vi khuẩn ki khí, Mycoplasma hominis [1]. Theo Javed (2019), viêm âm đạo không đặc hiệu là bệnh lý thường găp ở phu nữ, ước tính có từ $5-70 \%$ phư nữ mắc ít nhất một lần trong đời [1]. Ước tính có khoảng 21,2 triệu phụ nữ trên toàn thế giới hiện mắc. Các triệu chứng lâm sàng của bệnh khổng đặc hiệu như ngứa, kích thích, bỏng rát và tiết dịch bất thường ở âm hộ, âm đạo. Do đó, bệnh thường xuyên tái phát, dẫn tới sinh non, phá thai, rối loạn viêm vùng chậu hông và nhiễm trùng sau sinh [1],[2]. Tại Việt Nam, các báo cáo của Lê Hiếu Hạnh và cộng sự (2019), Đinh Thị Huyền Ngọc và cộng sự (2013) cho thấy viêm âm đạo không đặc hiệu thường gặp ở phụ nữ trong độ tuổi sinh sản, có tiền sử sản phụ khoa liên quan sảy thai, sinh non, đa phân xuất hiện không triệu chứng và chủ yếu chẩn đoán bằng các xét nghiệm cận lâm sàng như test sniff, tìm tế bào clue hay nhuộm gram [3],[4]. Do đó, 
chúng tôi tiến hành nghiên cứu với mục tiêu mô tả đặc điểm lâm sàng và cận lâm sàng của viêm âm đạo không đặc hiệu tại Bệnh viện Da liễu Trung ương từ tháng 8/2020 đến 8/2021.

\section{II. ĐỐI TƯợNG VÀ PHƯƠNG PHÁP NGHIÊN CỨU}

2.1. Đối tượng nghiên cứu. 39 phụ nữ có biểu hiện hội chứng tiết dịch âm đạo đến khám và điều trị tại Bệnh viện Da Liễu Trung ương từ tháng 8/2020 đến tháng 8/2021.

Bệnh nhân được chẩn đoán xác định viêm âm đạo không đặc hiệu theo tiêu chuẩn của Amsel (1983) khi có ít nhất 3 trong 4 tiêu chuẩn sau [1]: (1) Khí hư loãng trắng đồng nhất, dính vào thành âm đạo; (2) $\mathrm{pH}$ dịch âm đạo > 4,5; (3) Tế bào Clue Cells $\geq 20 \%$ tế bào biểu mô âm đạo; (4) Test sniff (test amin) dương tính.

\subsubsection{Tiêu chuẩn lựa chọn}

- Bệnh nhân nữ được chẩn đoán viêm âm đạo không đặc hiệu, từ 18 tuổi trở lên, đã có quan hệ tình dục.

\section{- Đồng ý tham gia nghiên cứu.}

2.1.2. Tiêu chuẩn loại trừ

- Bệnh nhân có thai, cho con bú.

- Bệnh nhân có tiền sử nhiễm HIV/AIDS hoặc có kết quả xét nghiệm HIV dương tính, test nhanh clamydia dương tính.

- Đang có biểu hiện viêm âm đạo cấp do Nấm, Trichomonas

- Ra máu âm đạo bất thường hoặc có các tổn thương loét trợt âm đạo nghi ngờ các bệnh lây truyền qua đường tình dục sau đây: Herpes, giang mai, sùi mào gà, hạ cam.

\subsection{Phương pháp nghiên cứu}

2.2.1. Thiết kế nghiên cứu: Mô tả cắt ngang

2.2.2. Cõ̃ mẫu: Cõ̃ mẫu thuận tiện

2.2.3. Các bước tiến hành nghiên cứu

* Khám lâm sàng:

- Bệnh nhân có biểu hiện ra khí hư âm đạo được hỏi bệnh, thăm khám, chỉ định xét nghiệm. Bệnh nhân được chẩn đoán viêm âm đạo khổng đặc hiệu có đủ $3 / 4$ tiêu chuẩn của Amsel được làm bệnh án nghiên cứu.

- Thu thập thông tin về tuổi, giới, nghề nghiệp, tình trạng hôn nhân, thói quen rửa vệ sinh, tiền sử sản phụ khoa 6 tháng trước, tiền sử điêu trị viêm âm đạo. Khám đánh giá triệu chứng cơ năng: khí hư, mùi khí hư, ngứa rát âm hộ, bỏng rát âm đạo, giao hợp đau, đái buốt, đái rắt, đau bụng dưới, không triệu chứng. Triệu chứng thực thể: đánh giá mức độ viêm đỏ của âm hộ, âm đạo. Khám đánh giá dịch âm đạo: số lượng, màu sắc, tính chất, mùi.

* Cận lâm sàng
- Test Sniff

- Nhuộm Gram khí hư âm đạo:

+ Tìm Clue cells: Là những tế bào biểu mô âm đạo bong ra, bị hấp thu bởi các trực khuẩn Gram âm nhỏ trên bề mặt hoặc xung quanh tế bào.

+ Tìm các loại vi khuẩn có trong âm đạo: trực khuẩn Gram dương, trực khuẩn Gram ẩm, cẩu khuẩn Gram dương. Tìm bạch cầu.

+ Đánh giá hệ vi sinh vật âm đạo theo tiêu chuẩn Nugent: chẩn đoán dựa trên thang điểm từ 0 đến 10 , trong đó điểm từ 0 đến 3 là bình thường, điểm 7 trở lên là viêm âm đạo không đặc hiệu (BV) và điểm từ 4 đến 6 được cho là trung gian.

+Tìm vi khuẩn lactobacilli. Số lượng vi khuẩn lactobacili được đếm trên kính hiển vi độ phóng đại 1000 và số lượng vi khuẩn trên một vi trường chia thành các nhóm: <6 tương đương là $(-), 6-$ 20 tương đương với $(1+), 21-50$ tương đương với (2+) hoặc >50 tương đương với (3+).

+Đánh giá độ thuần khiết của hệ vi khuẩn hay độ lactobaciili theo Schroeder và được Donders chỉnh sửa như sau [5]: Độ 0 (Không có vi khuẩn); Độ I (Lactobacilli chiếm ưu thế với rất ít vi khuẩn khác); Độ Iia (Có Lactobacilli giảm dần và các vi khuẩn khác, trong đó, hệ vi sinh vật khá bình thường, chưa rối loạn nhiều); Độ Iib (Có Lactobaciili giảm dần và các vi khuẩn khác, trong đó, hệ vi sinh vật rối loạn); Độ III (Có nhiều vi khuẩn khác mà không có lactobacilli).

2.3. Phương pháp xử lý số liệu. Xử lý số liệu theo phương pháp thống kê y học, sử dụng phần mềm SPSS 23.0. Sự khác biệt giữa 2 nhóm nghiên cứu có ý nghĩa thống kê nểu $\mathrm{p}<0,05$.

\section{KẾT QUẢ NGHIÊN CỨU}

Từ tháng $8 / 2020$ đến tháng $8 / 2021$, có 39 bệnh nhân viêm âm đạo không đặc hiệu thỏa mãn tiêu chuẩn lựa chọn được đưa vào nghiên cứu. Kết quả như sau:

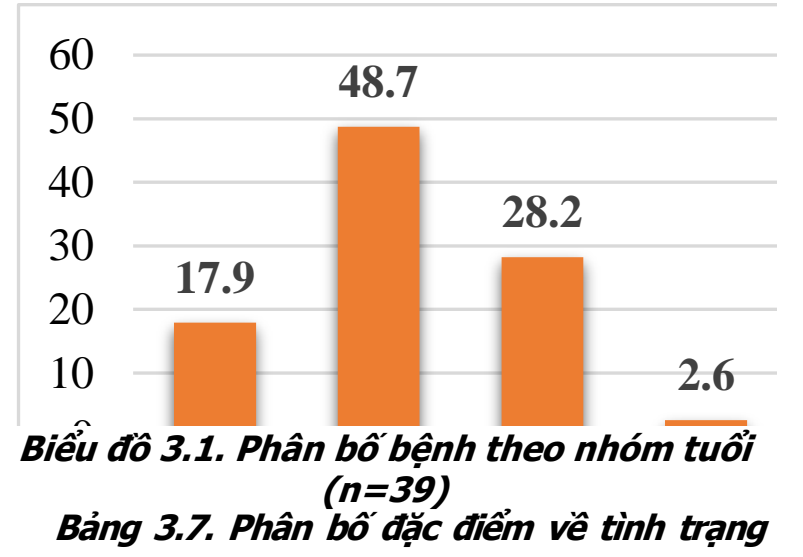


VIETNAM MEDICAL JOURNAL N02 - NOVEMBER - 2021

\begin{tabular}{|c|c|c|c|}
\hline \multicolumn{2}{|c|}{ Đăc điếm } & $\mathbf{n}$ & $\%$ \\
\hline \multirow{2}{*}{$\begin{array}{l}\text { Tình trạng } \\
\text { hôn nhân }\end{array}$} & Đã kết hôn & 20 & 51,3 \\
\hline & Chưa kết hôn & 19 & 48,7 \\
\hline \multirow{2}{*}{$\begin{array}{l}\text { Thói quen } \\
\text { vệ sinh }\end{array}$} & <2 lần/ngày & 20 & 51,3 \\
\hline & 22 lânn/ngày & 19 & 48,7 \\
\hline \multirow{4}{*}{$\begin{array}{c}\text { Tiền sử } \\
\text { điều trị } \\
\text { bệnh sản } \\
\text { phụ khoa }\end{array}$} & Nạo, hút thai & 13 & 33,3 \\
\hline & Sáy thai & 4 & 10,3 \\
\hline & $\begin{array}{l}\text { Mắc bệnh sản } \\
\text { phụ khoa khác }\end{array}$ & 16 & 41 \\
\hline & Không có tiền sử & 6 & 15,4 \\
\hline \multirow{4}{*}{$\begin{array}{l}\text { Tiên sử } \\
\text { điều trị } \\
\text { viêm âm } \\
\text { đao }\end{array}$} & Chưa điều trị & 13 & 33,3 \\
\hline & Điều trị 1 lần & 11 & 28,2 \\
\hline & Điều trị 2 lần & 5 & 12,8 \\
\hline & Điều tri $\geq 3$ lần & 10 & 25,6 \\
\hline
\end{tabular}

Bảng 3.8. Phân bồ triệu chứng thực thể của nhóm bệh nhân (n=39)

\begin{tabular}{|c|c|c|c|}
\hline \multicolumn{2}{|c|}{ Triệu chứng } & $\mathbf{n}$ & $\mathbf{\%}$ \\
\hline \multirow{4}{*}{ Khí hư } & Trong, nhày dính & 1 & 2,6 \\
\cline { 2 - 4 } & $\begin{array}{c}\text { Trắng loãng, xám đồng } \\
\text { nhất }\end{array}$ & 22 & 56,4 \\
\cline { 2 - 4 } & Vàng xanh có bọt & 13 & 33,3 \\
\cline { 2 - 4 } & Trắng như váng sữa bọt & 3 & 7,7 \\
\hline
\end{tabular}

\begin{tabular}{|c|c|c|c|}
\hline & có vón cục & & \\
\hline Dịch âm & Ít & 12 & 30,8 \\
\cline { 2 - 4 } đạo & Nhiều & 27 & 69,2 \\
\hline $\begin{array}{c}\text { Thành } \\
\text { âm hộ, } \\
\text { âm đạo }\end{array}$ & Bình thường & 15 & 38,5 \\
\cline { 2 - 4 } & Viêm đỏ & 24 & 61,5 \\
\hline
\end{tabular}

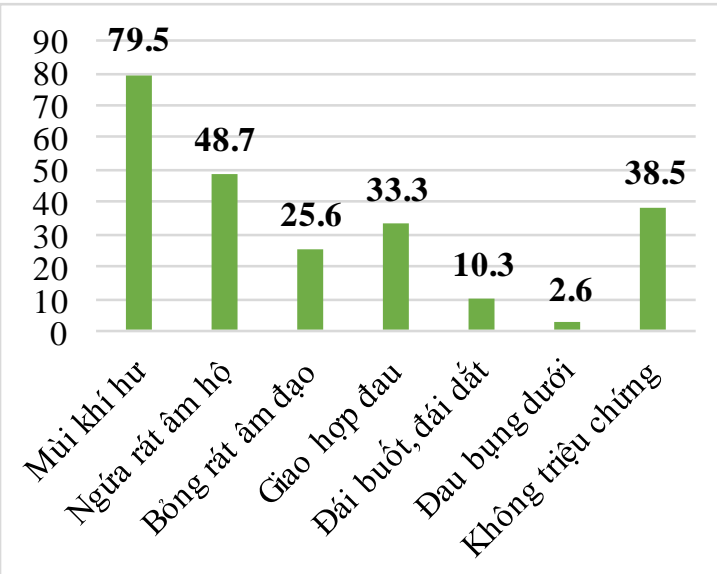

Biểu đồ 3.2. Phân bố triệu chứng cơ năng của nhóm bệnh nhân (n=39)

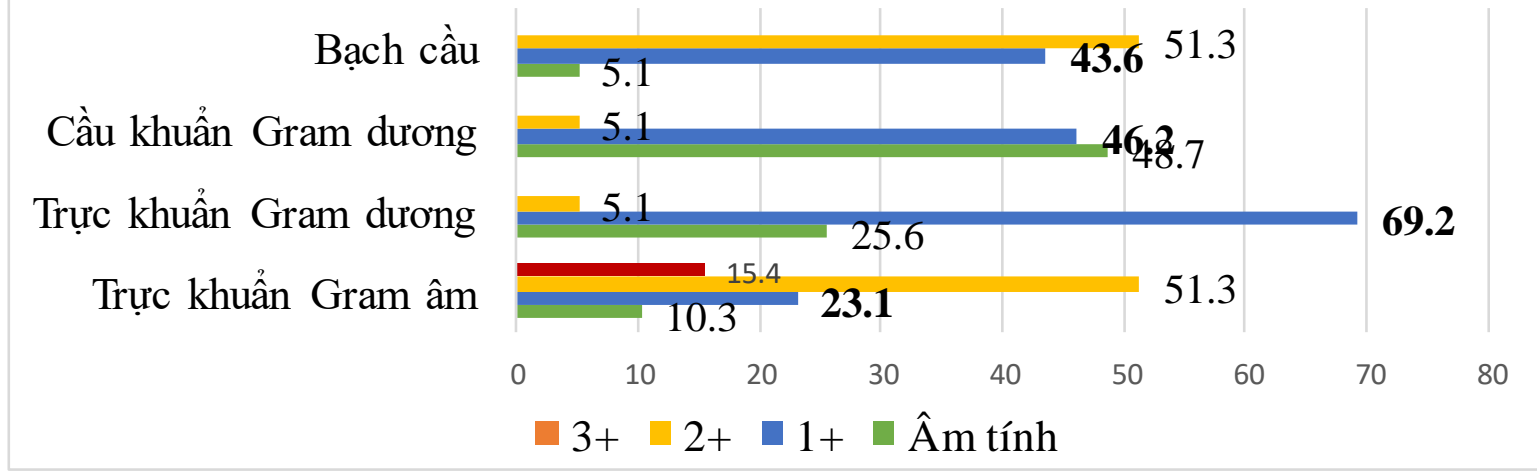

Biểu đồ 3. 3.Phân bố số lượng vi khuẩn và bạch cầu theo kết quả nhuộm soi dịch âm đạo (n=39)

Bảng 3.9. Phân bố chẩn đoán hệ vỉ sinh vật theo điểm Nugent, số lượng vi khuân lactobacilli và phân độ theo Schroeder và Donders ( $n=39)$

\begin{tabular}{|c|c|c|c|}
\hline \multirow{2}{*}{$\begin{array}{c}\text { Đặc điểm } \\
\text { Chẩn đoán } \\
\text { theo Nugent }\end{array}$} & $\begin{array}{c}\text { Bình thường } \\
\text { (0-3 điểm) }\end{array}$ & 0 & 0 \\
\cline { 2 - 4 } & $\begin{array}{c}\text { Trung gian (4-6 } \\
\text { điểm) }\end{array}$ & 23 & 59,0 \\
\cline { 2 - 4 } & $\begin{array}{c}\text { Viêm âm đạo } \\
\text { không đăc hiêuu } \\
\text { (7-10 điểm) }\end{array}$ & 16 & 41,0 \\
\hline $\begin{array}{c}\text { Số lượng } \\
\text { Lactobacilli }\end{array}$ & $\begin{array}{c}\text { Không có vi } \\
\text { khuẩn }\end{array}$ & 9 & 23,1 \\
\cline { 2 - 4 } & Dương tính 1+ & 28 & 71,8 \\
\hline
\end{tabular}

\begin{tabular}{|c|c|c|c|}
\hline & Dương tính 2+ & 2 & 5,1 \\
\hline Độ lactobacilli & Độ IIa & 10 & 25,6 \\
\cline { 2 - 4 } theo Schroeder & Độ IIb & 20 & 51,3 \\
\cline { 2 - 4 } và Donders & Đồ III & 9 & 23,1 \\
\hline \multicolumn{2}{|r|}{ Tống số } & 39 & 100 \\
\hline
\end{tabular}

\section{BÀN LUẬN}

Về tình trạng hôn nhân và thói quen vệ sinh: $Y$ văn ghi nhận, hầu hết các trường hợp viêm âm đao không đắc hiêu đều găp ở phụ nữ trong độ tuổi sinh sản và đã có quan hê tình dục. Kết quả nghiên cứu của chúng tôi ở bảng 3.1 chỉ ra không có sự khác biệt giữa nhóm đã kết hôn và chưa kết hôn. Ranjit và cộng sự (2018) so sánh giữa nhóm phụ nữ đã lập gia đình và chưa 
kết hôn phát hiện, 100\% trường hợp chưa kết hôn mắc bệnh so với $24,2 \%$ ở nhóm đã kết hôn [6]. Theo tác giả, hoạt động tình dục không phải là điều kiện tiên quyết cho sự hình thành bệnh viêm âm đạo không đặc hiệu mà những sự thay đổi trong lối sống cũng như các thói quen chăm sóc không phù hợp ảnh hưởng đến bệnh [6]. Tuy vậy, trong nghiên cứu này, nhóm nghiên cứu không tìm thấy sự khác biệt giữa nhóm vệ sinh thụt rửa âm đạo <2 lần/ngày và $\geq 2$ lần/ngày. Felix và cộng sự (2020) tìm hiểu mối liên quan giữa thói quen vệ sinh và viêm âm đạo phát hiện, tỉ lệ viêm âm đạo không đặc hiệu chiếm đa số $83,3 \%$ có xu hướng gặp nhiều hớn ở nhóm vệ sinh âm đạo không đầy đủ cũng như thiếu thông tin về các thực hành vệ sinh đúng cách. Tác giả cho rằng, xà phòng với thành phần có thể hòa tan chất béo, độ $\mathrm{pH}$ trung tính/kiềm khi sử dụng thường xuyên có thể gây nên kết quả không mong muốn như khô và giảm độ acid. Kamga và cộng sự (2019) nhận thấy phụ nữ có thói quen thụt rửa âm đạo có nguy cơ mắc viêm âm đạo không đặc hiệu cao hơn so với không thực hiện [2]. Mặc dù vậy, theo nhóm nghiên cứu, khồng có mối liên quan giữa tình trạng hôn nhân, thói quen thụt rửa âm đạo nhiêu lần và tình trạng viêm nhiếm âm đạo không đặc hiệu.

Về tiên sử bệnh: Viêm âm đạo không đặc hiệu là bệnh lý thường xuyên tái phát, và có mối liên quan mật thiết với tỉ lệ sảy thai cũng như sinh non. Tỉ lệ viềm âm đạo không đặc hiệu ở phụ nữ mang thai là từ $10-41 \%$ và có mối liên quan với tỉ lệ phá thai, sinh non, nhiễm trùng nước ối, võ ối sớm, viêm nội mạc tử cung sau sinh và nhiễm khuẩn hậu sản[7]. Đinh Thị Huyền Ngọc và cộng sự (2013) phát hiện $13,6 \%$ bệnh nhân có tiền sử đẻ non, 20,5\% bểnh nhân sảy thai trong 65 phụ nữ viêm âm đạo không đặc hiệu [4]. Tuy nhiên, tác giả cho rằng, sảy thai thường liên quan đến bất thường nhiểm sắc thể, các bệnh toàn thân của mẹ, dị dạng tử cung và nội tiết mà không có mối liên quan với viêm âm đạo. Kamga và cộng sự (2019) tìm thấy 26,2\% phụ nữ mang thai mắc viêm âm đạo không đặc hiệu, trong đó, có $20 \%$ tiền sử phá thai, 25,7\% tiền sử sảy thai trước đó[2]. Nghiên cứu của chúng tôi có $10,3 \%$ bệnh nhân sảy thai, 30,3\% bệnh nhân nạo hút thai. Kết quả này tương đồng với các nghiên cứu trước đó, viêm âm đạo không đặc hiệu có mối liên quan với các biến chứng sản khoa.

Về triệu chứng: Triệu chứng cơ năng rất thường gặp trong viêm âm đạo không đặc hiệu nhưng là dấu hiệu sớm nhất biểu hiện của tình trạng kích ứng tại âm đạo do rối loạn hệ vi sinh vật. Kết quả được trình bày ở biểu đồ 3.2 cho thấy $79,5 \%$ bệnh nhân có mùi khí hư, $48,7 \%$ ngứa rát âm hộ, $25,6 \%$ bỏng rát âm đạo, 10,3\% đái buốt, đái rắt, $2,6 \%$ đau bụng dưới và $33,3 \%$ có biểu hiện giao hợp đau. Tỉ lệ này tương đồng với nghiên cứu của Đinh Thị Huyền Ngọc (2013), giao hợp đau chiếm đa số với $66,7 \%$, tiếp theo là đái buốt, đái rắt $39,4 \%$, bỏng rát âm đạo $24,2 \%$ và ngứa rát âm hộ $6,1 \%[4]$. Trong nghiên cứu này có $49,2 \%$ bệnh nhân không có triệu chứng, cao hơn của chúng tôi là $38,5 \%$. Nghiên cứu của Ranjit và cộng sự (2018) cũng cho thấy tỉ lệ bệnh nhân viêm âm đạo không đặc hiệu có mùi khí hư, lượng dịch nhiều, đau bụng, ngứa cao hơn so với nhóm không viêm âm đạo[6]. Nhóm nghiên cứu cho rằng, mặc dù chưa được công nhận là một bệnh lây truyền qua đường tình dục nhưng viêm âm đạo không đặc hiệu có thể xểp vào nhóm các bệnh này bởi vì tần suất xuất hiện ở đối tượng có hoạt động tình dục cũng như các biểu hiện cơ nắng. Có những bằng chứng dịch tễ học từ một số nghiên cứu thiết lập mối liển quan giữa viêm âm đạo không đặc hiệu và tăng số lượng bạn tình, sử dụng bao cao su không nhất quán cũng như quan hệ tình dục sớm [2],[8]. Điều này thể hiện là biểu hiện giao hợp đau hay bỏng rát âm đạo xuất hiện rất sớm ở nhóm bệnh nhân này. Hơn nữa, với đặc trưng là sự rối loạn vi hệ bình thường của hệ vi sinh vật, không hoạt động tình dục cũng có thể là nguyên nhân mà có một lượng lớn bệnh nhân không có triệu chứng cơ năng mặc dù có ra khí hư cũng như các biểu hiện lâm sàng khác.

Vê Lactobacilli: Kết quả bảng 3.3 cho thấy số lượng lactobacilli dương tính 1+ chiếm đa số với $71,8 \%$, tiếp theo là nhóm không có vi khuẩn với $23,1 \%$, không có trường hợp nào dương tính 3+. Tamrakar và cộng sự (2007) phân tích trên 132 mẫu bệnh phẩm từ phụ nữ mang thai phát hiện chi lactobacillus xuất hiện ở hầu hết phụ nữ với bất kỳ điểm số Nugent nào [7]. Trong đó, tác giả tìm thấy chủng $L$. crispatus, $L$. jensenii và $L$. gasseri cao hơn đáng kể ở nhóm bình thường so với nhóm viêm âm đạo không đặc hiệu, trong khi chủng L. iners không có sự khác biệt. Một phân tích khác so sánh tî lệ lactobacilli giữa phụ nữ bình thường và mắc viêm âm đạo không đặc hiệu, tác giả Chooruk nhận thấy lactobacilli chiếm ưu thế ở nhóm bình thường và giảm rõ rệt ở nhóm mắc bệnh [8]. Đồng thời, đối với những trường hợp viêm âm đạo không đặc hiệu đã điều trị, số lượng lactobacilli cũng tăng lên đáng kể. Kết quả này phù hợp với chúng tôi mặc dù trong 
nghiên cứu này, tác giả sử dụng phương pháp nuôi cấy để đánh giá số lượng khuẩn lạc lactobacilli. Phương pháp đánh giá trên nhuộm gram hệ vi sinh vật cũng được Yan và cs (2009) sử dụng trên 150 phụ nữ tại Bắc Kinh [9]. Kết quả cho thây, phần lớn bệnh nhân viêm âm đạo không đặc hiệu được phân độ lactobacilli độ III $(91 \%, 42 / 46$ trường hợp) và độ II $(9 \%, 4 / 46$ trường hợp); trong khi đó, nhóm phụ nữ khỏe mạnh có $64 \%$ độ I (67/104 trường hợp) và $36 \%$ độ II (37/104 trường hợp). Kết quả này tương đồng với nghiên cứu của chúng tôi được trình bày ở bảng 3.9 , độ II chiếm $76,9 \%$ và độ III chiếm $23,1 \%$ và không có trường hợp nào độ $I$. Như vậy, trong viêm âm đạo không đặc hiệu có sự suy giảm về mặt số lượng lactobacilli cũng như các loài lactobacilli.

\section{KẾT LUẬN}

Viêm âm đạo không đặc hiệu có xu hướng gặp ở đối tượng trẻ tuổi từ 18-30, có tỉ lệ gặp cao hơn ở nhóm có tiền sử bênh liên quan nao hút thai, sảy thai. Đa số bệnh nhân có biểu hiện triệu chứng trong đó thường gặp là mùi khí hư, ngứa rát âm hộ, giao hợp đau. Xét nghiệm cho thấy sự rối loạn của hệ vi sinh vật tại âm đạo, số lượng lactobacilli suy giảm và gia tăng các loài vi khuẩn gram âm, câu khuẩn gram dương khác.

\section{TÀl LIÊU THAM KHẢO}

1. Javed A., Parvaiz F., Manzoor S. (2019). Bacterial vaginosis: An insight into the prevalence, alternative treatments regimen and it's associated resistance patterns. Microb Pathog, 127, 21-30.
2. Kamga Y.M., Ngunde J.P., Akoachere J.K.T. (2019). Prevalence of bacterial vaginosis and associated risk factors in pregnant women receiving antenatal care at the Kumba Health District (KHD), Cameroon. BMC Pregnancy Childbirth, 19(1), 1-8.

3. Lê Hiếu Hanh, Lê Thái Vân Thanh, Văn Thế Trung (2019). Viêm âm đạo và các yễu tố liên quan ở bệnh nhân nữ tại Bệnh viện Da liễu TP. Hồ Chí Minh. Y học TP. Hồ Chí Minh, 23(1), 38-44.

4. Đinh Thị Huyền Ngọc (2013), Nghiên cứu hiệu quả điều tri của Gynoflor trong viêm âm đao không đặc hiệu tại Bệnh viện Phụ Sản Trung Ương, Luận vẳn Thạc sỹ y học, Đại học Y Hà Nội.

5. Faisal M.M., Abdel-Gawad M.M., Fahmy R.A. et al (2019). Change in Vaginal Flora as Indicated by Pap Smear (Schröder's Classification) in Women Using Levonorgestrel-Releasing Intrauterine System "Mirena"-Prospective Cohort Study. Open Journal of Obstetrics and Gynecology, 9(5), 631-642.

6. Ranjit E., Raghubanshi B.R., Maskey S. et al (2018). Prevalence of Bacterial Vaginosis and Its Association with Risk Factors among Nonpregnant Women: A Hospital Based Study. Int J Microbiol, 2018, 1-9.

7. Tamrakar R., Yamada T., Furuta I. et al (2007). Association between Lactobacillus species and bacterial vaginosis-related bacteria and bacterial vaginosis scores in pregnant Japanese women. BMC Infectious Diseases, 7(1), 128.

8. Chooruk A., Utto P., Teanpaisan $R$. et al (2013). Prevalence of lactobacilli in normal women and women with bacterial vaginosis. J Med Assoc Thai, 96(5), 519-522.

9. Yan D.H., Lü Z., Su J.R. (2009). Comparison of main lactobacillus species between healthy women and women with bacterial vaginosis. Chin Med J (Engl), 122(22), 2748-2751.

\section{ĐÁNH GIÁ KẾT QUẢ ĐIÎ̀U TRỊ HộI CHỨNG THÂ̂N HƯ TIÊN PHÁT Ở TRẺ EM TẠI THÁI NGUYÊN}

\section{TÓM TẮT}

Mục tiêu: Đánh giá kết quả điều trị hội chứng thân hư tiên phát ở trẻ em tai Thái Nguyên. Đối tượng: 30 bệnh nhi được chẩn đoán Hội chứng thận hư tiêp phát vào điều trị tại Bênh viện Trung Ương Thái Nguyên và Bệnh viện $A$ Thái Nguyên từ tháng $01 / 2019$ đến tháng 06/2021. Phương pháp nghiên cứu: Nghiên cứu mô tả cắt ngang. Kết quả: Nam mắc bệnh nhiều hơn nữ với tỷ lệ 4/1 (có 24 nam và 6

*Trường Đại hơ Y Dước - ĐH Thái Nguyên

Chịu trách nhiệm chính: Trương Thị Hồng Minh

Email: hongminhbsdk.dhyd@gmail.com

Ngày nhận bài: 19.8.2021

Ngày phản biên khoa hoc: 18.10.2021

Ngày duyệt bài: 29.10.2021

\section{Trương Thị Hồng Minh*, Nguyễn Văn Sơn*}

nữ). Tuổi trung bình mắc bệnh là 6,1 tuổi; nhóm tuổi 5-10 tuổi chiếm $63,3 \%$. Các bệnh nhi trong nghiên cứu có tỷ lệ phù $100 \%$, tăng huyết áp (40\%), thiểu niệu $(26,7 \%)$, protein niêuu 24 giờ trung bình 163,26 $\mathrm{mg} / \mathrm{kg} / 24 \mathrm{~h}$, albumin máu giảm nặng (trung bình 17,42 $\mathrm{g} / \mathrm{l}$ ), cholesterol tăng cao (trung bình $9,76 \mathrm{mmol} / \mathrm{l}$ ). Đáp ứng điều trị với corticosteroid là $76,7 \%$ với thới gian đáp ứng trung bình là 11,73 ngày. Tỷ lệ tái phát sau 3 tháng điêu trị là $36,67 \%$, trong đó chủ yếu là bệnh nhân thể kết hợp (87,5\%). Kết luân: Bệnh nhi mắc hội chứng thận hư tiên phát gặp phần lớn ở trẻ nam, chủ yếu lứa tuổi học đường, triệu chứng chủ yếu là phù, giảm năng albumin máu và protein niêuu tăng cao. Bệnh đáp ứng tốt với thuốc corticosteroid. Tỷ lệ bênh nhân tái phát chủ yếu ở nhóm hôi chứng thân hư tiên phát kết hợp. Tứ khóa: Trẻ em, hội chứng thận hư tiên phát, điêu trị 